\title{
Model Pembelajaran Kolaboratif Meningkatkan Hasil Belajar Matematika Siswa
}

\author{
Kadek Beny Agus Permana1, Ndara Tanggu Renda², I Gede Margunayasa ${ }^{3}$ \\ 1,2,3 Jurusan Pendidikan Dasar, Universitas Pendidikan Ganesha \\ Singaraja, Indonesia \\ e-mail: beniaguspermana@gmail.com ${ }^{1}$,ndaratanggu.renda@undiksha.ac.id², \\ igede.margunayasa@undiksha.ac.id ${ }^{3}$.
}

\begin{abstract}
Abstrak
Rendahnya hasil belajar matematika siswa di sekolah dasar dan belum diketahuinya apakah terdapat pengaruh yang signifikan model pembelajaran kolaboratif terhadap hasil belajar matematika siswa. menjadi permasalahan utama pada penelitian ini. Hal tersebut disebabkan oleh kurangnya pemahaman guru dalam menerapkan model pembelajaran yang inovatif pada proses belajar. Penelitian ini memiliki tujuan untuk mengetahui pengaruh model pembelajaran Kolaboratif terhadap hasil belajar matematika siswa kelas $\mathrm{V}$ SD. Jenis penelitian ini adalah eksperimen semu (quasi eksperiment) dengan rancangan post-test only control group design. Populasi penelitian ini adalah siswa kelas V SD yang berjumlah 401 siswa. Sampel penelitian ini adalah kelas V(A) SDN 1 Astina, dan kelas V SDN 1 Penarukan dengan jumlah 55 orang sebagai kelompok eksperimen, untuk kelompok kontrol pada penelitian ini adalah kelas V(B) SDN 1 Astina, dan kelas V SDN 4 Penarukan dengan jumlah 49 orang sebagai kelompok kontrol, dengan teknik multistage random sampling. Pengumpulan data dalam penelitian ini dilakukan menggunakan metode tes dengan instrument tes objektif berupa tes pilihan ganda yang berjumlah 20 butir soal objektif. Data yang terkumpul dianalisis menggunakan analisis statistik deskriptif dan inferensial (uji-t). Hasil uji-t diperoleh thitung lebih besar dari tabel $(7,09>1,983)$ sehingga $\mathrm{H} 0$ ditolak dan $\mathrm{H} 1$ diterima. Dari hasil analisis uji-t dan rata-rata hasil belajar tersebut, dapat disimpulkan bahwa model pembelajaran Kolaboratif berpengaruh terhadap hasil belajar Matematika siswa kelas V SD di Gugus II dan Gugus IX Kecamatan Buleleng. Oleh sebab itu, model pembelajaran kolaboratif cocok diterapkan untuk mengatasi hasil belajar matematika siswa yang rendah.
\end{abstract}

Kata kunci: kolaboratif, hasil belajar, matematika

\begin{abstract}
The low student mathematics learning outcomes in primary schools and it is not yet known whether there is a significant effect of collaborative learning models on student mathematics learning outcomes are the main problem in this research. That is caused by the lack of understanding of teachers in applying innovative learning models in the learning process. This study aimed to determining the effect of the Collaborative learning model on mathematics learning outcomes of fifth grade elementary school students. The type of this research is a quasi-experimental with a post-test only control group design. The population of this research was the fifth grade students elementary School, which amounted to 401 students. The sample of this study was class V (A) SDN 1 Astina, and class V SDN 1 Penarukan total 55 people as the experimental group, for the control group in this study were class V (B) SDN 1 Astina, and class V SDN 4 Penarukan with number of 49 people as a control group, with a multistage random sampling technique. Data collection in this study was conducted using a test method with an objective test instrument in the form of multiple choice tests totaling 20 objective items. The collected data were analyzed using descriptive and inferential statistical analysis (t-test). The t-test results obtained $t$-count greater than $t$ table $(7.09>1.983)$ so that $\mathrm{H} 0$ is rejected and $\mathrm{H} 1$ is accepted. From the results of the t-test analysis and the average learning outcomes, it can be concluded that the Collaborative learning model influences the learning outcomes
\end{abstract}


of Mathematics students in grade V elementary schools in Cluster II and Cluster IX Buleleng District. Therefore, the collaborative learning model is match to be applied to overcome the low student in learning mathematics.

Keywords: collaborative, the result of study, mathematics

\section{Pendahuluan}

Pendidikan pada perkembangan IImu Pendidikan dan Teknologi (IPTEK) di abad 21, dipandang sebagai sebuah kebutuhan yang harus dipenuhi setiap manusia. Setiap individu dituntut agar lebih meningkatkan kemampuannya dalam segala bidang kehidupan melalui Pendidikan. Semakin tinggi kualitas pendidikan masyarakat di suatu negara, maka kualitas kehidupan bangsa pun juga akan meningkat. Bagi kehidupan manusia, pendidikan merupakan kebutuhan mutlak yang harus didapatkan oleh setiap individu karena tanpa adanya pendidikan mustahil manusia dapat hidup berkembang untuk maju, sejahtera dan Bahagia. Pemerintah pada saat ini terus menerus dengan berbagai macam upaya secara berkesinambungan melakukan evaluasi proses belajar dikelas guna meningkatkan kualitas Pendidikan yaitu salah satunya dengan menyempurnakan kurikulum pendidikan dengan memberlakukan kurikulum 2013. Dirancangnya Kurikulum 2013 bertujuan "mempersiapkan insan Indonesia agar memiliki kemampuan hidup sebagai pribadi yang beriman, produktif, inovatif, dan aktif serta mampu berkontribusi pada kehidupan bermasyarakat, berbangsa, dan bernegara" (Japa \& Suarjana, 2014:5)

Salah satu mata pelajaran pokok yang dibelajarkan dalam setiap jenjang pendidikan dasar di Indonesia adalah matematika. Matematika juga merupakan "suatu ilmu yang berkembang baik dari sisi materi maupun manfaatnya bagi masyarakat" (Monawati \& Yamin, 2016:13). Matematika merupakan disiplin ilmu yang universal yang mempunyai peranan penting dalam memajukan daya pikir manusia dan juga mendasari teknologi dalam berbagai disiplin ilmu (Hariadi, 2019). Mata pelajaran matematika merupakan salah satu komponen pendidikan yang berperan penting dalam proses perhitungan serta berpikir untuk menyelesaikan suatu permasalahan (Susanto, 2013). Pembelajaran matematika di sekolah dasar merupakan suatu proses interaksi antara guru dengan siswa yang dilakukan secara sadar yang bertujuan agar siswa memahami konteks matematika yang diajarkan (Hayati, dkk, 2018).

Dibelajarkannya matematika kepada semua peserta didik mulai dari tingkat sekolah dasar (SD) adalah untuk membekali siswa berbagai kemampuan baik dalam berpikir sistematis dan kritis maupun kemampuan bekerjasma siswa (Japa \& Suarjana, 2015). Selain itu dibelajarkannya matematika di sekolah dasar karena matematika merupakan salah satu ilmu yang memiliki peranan sangat penting dalam pendidikan yang dapat diterapkan dalam semua aspek kehidupan. Selain itu matematika juga berperan penting dalam mempersiapkan siswa dalam menghadapi kemajuan global (Mahendra, dkk, 2018). Menurut Hariadi (2019) disiplin ilmu yang dianggap sebagai ilmu yang sulit untuk dipahami adalah matematika, hal ini dikarenakan ilmu matematika dianggap abstrak, tidak hanya pada siswa tingkat sekolah dasar saja bahkan hingga mahasiswa di perguruan tinggi. Pendapat serupa juga disampaikan oleh Warti (2018) bahwa belajar matematika selalu identik dengan hitungan, sehingga siswa malas dan takut dalam pelajaran tersebut dan takut salah. Salah satu faktor dari dinggapnya matematika sebagai ilmu yang sulit tidak lepas dari peran guru dalam membelajarkan matematika dalam proses pemebelajaran. Dalam proses pembelajaran guru harus kreatif dalam mewujudkan suasana pembelajaran yang menyenangkan (Sribawana, dkk, 2017).

Kenyataannya pembelajaran matematika yang terjadi di lapangan tidaklah seperti yang diharapkan karena hasil belajar matematika sebagian besar peserta didik masih tergolong rendah. Menurut hasil survei Program for International student Assessment (PISA) tahun 2018, khusunya pada kategori matematika, Indonesia berada pada peringkat 73 dari 80 negara yang mengikuti program ini dengan skor rata-rata 379. Skor rata-rata Indonesia tersebut bila dibandingkan dengan negara Cina yang berada pada peringkat pertama dengan skor rata-rata 591 masih sangatlah jauh (Permana, 2019). Rendahnya hasil belajar 
matematika siswa disebabkan oleh kurang menariknya pembelajaran di kelas sehingga siswa merasa jenuh yang membuat minat belajar siswa hilang. Selain itu, rendahnya hasil belajar matematika siswa disebabkan sebagian besar siswa tidak menyukai pelajaran matematika dengan alasan matematika dianggap pelajaran yang rumit, banyak rumus yang dihapal, serta penuh dengan angka-angka (Ardila \& Hartanto, 2017). Adapun beberapa faktor yang mempengaruhi hasil belajar siswa adalah Hasil belajar dapat dipengaruhi oleh beberapa faktor, baik faktor dari dalam (faktor internal) adalah faktor fisiologis dan faktor psikologis misalnya kecerdasan, motivasi berprestasi, dan kemampuan kognitif maupun faktor dari luar (faktor eksternal) adalah faktor lingkungan dan faktor instrumental misalnya guru, kurikulum, dan model pembelajaran (Anggarawati, Kristiani, \& Asri, 2014).

Demikian juga yang terjadi di SD pada gugus II dan IX bahwa hasil matematika siswa tergolong rendah. Hal ini didukung oleh hasil wawancara, observasi, peneyebaran kuesioner maupun hasil studi dokumentasi kelas yang dilakukan pada Sabtu, 16 November 2019 sampai dengan Rabu, 20 November 2019 pada SD di Gugus II dan IX Kecamatan Buleleng. Dari penyebaran kuesioner ke masing-masing guru kelas V di SD Gugus II dan IX Kecamatan Buleleng, didapatkan hasil bahwa $67 \%$ guru masih belum mengetaui mengenai model pembelajaran kolaboratif. Berdasarkan hasil wawancara dengan guru kelas $V$ di SD Gugus II dan IX Kecamatan Buleleng didapatkan beberapa masalah yakni, bahwa (1) Siswa sangat pasif dalam pembelajaran berkelompok maupuan pembelajaran klasikal; (2) Kurangnya media pendukung dalam menunjang proses pembelajaran pada mata pelajaran matematika; (3) Guru masih belum memahami mengenai model pembelajaran inovatif pada pembelajaran Matematika; (4) Hasil belajar Matematika siswa yang masih rendah dan belum memenuhi KKM.

Dalam observasi juga juga tampak masalah yang tidak jauh beda yakni, (1) Guru masih cenderung menggunakan metode ceramah tanpa memberikan variasi dengan metode-metode lain; (2) Siswa kurang memperhatikan pada saat guru sedang menjelaskan; (3) Siswa kurang akif dalam menyelesaikan tugas yang diberikan guru. Untuk melengkapi hasil penyebaran kuesioner, wawancara dan observasi maka dilakukan studi dokumentasi kelas V pada SD di Gugus II dan IX Kecamatan Buleleng berupa nilai UTS matematika. Berdasarkan studi dokumentasi, hasil belajar matematika siswa berupa nilai UTS matematika tergolong rendah. Dari jumlah keseluruhan siswa kelas V SD Gugus II dan IX Kecamatan Buleleng yang berjumlah 401 siswa, masih terdapat 204 siswa yang apabila dipersentasekan $51 \%$ nilai matematika siswa masih belum memenuhi KKM. Hasil belajar ialah perubahan prilaku siswa baik perubahan peningkatan sikap, peningkatan pengetahuan, maupun keterampilan siswa setelah siswa mengikuti dan menyelesaikan proses belajar mengajar di kelas (Pratiwi, 2015). Pencapaian hasil belajar siswa akan maksimal apabila proses pembelajaran di kelas mampu memotivasi siswa dalam belajar. Ada beberapa hal yang menyebabkan hasil belajar matematika siswa rendah yaitu siswa kurang aktif dalam pembelajaran, siswa lebih mampu mengafal daripada memahami, pembelajaran hanya berpusat pada guru, dan guru hanya menggunakan metode ceramah dalam mengajar.

Merujuk pada permasalah tersebut, perlu dirasanya untuk meciptakan proses belajar yang leboh kreatif, inovatif dan menyenangkan di dalam kelas. Hal ini dikarenkan apabila masalah tersebut tidak ditindak lanjuti maka akan berdampak pada rendahnya hasil belajar matematika siswa, seperti hasil survei PISA tahun 2018 yang sudah dipaparkan di atas. Untuk menciptakan suasana pembelajaran yang menarik minat siswa dalam mengikuti pembelajaran di kelas guna memperoleh hasil belajar matematika yang lebih maksimal, maka diperlukan suatu upaya untuk meningkatkan mutu pendidikan dan pembelajaran yaitu dengan memilih model dan strategi yang tepat dalam pembelajaran. Maka upaya yang dapat dilakukan untuk mengatasi masalah tersebut yaitu dengan menggunakan model pembelajaran kolaboratif. Hal ini didukung penelitian terduhulu yang dilakukan oleh Marhamah, dkk (2017) yang menyatakan penggunaan model pembelajaran Kolaboratif pada saat belajar berhasil memberikan dampak positif terhadap hasil belajar siswa. Menurut (Setyaningsih, 2014) model pembelajaran kolaboratif merupakan model yang didasari oleh teori interaksional yang memandang bahwa melalui interaksi sosial proses belajar dapat 
membangun makna seseorang. Dalam proses pembelajaran, belajar kolaboraif menempati posisi yang strategis karena model kolaboratif mampu mengkondisikan peserta didik untuk mendapatkan kemajuan dalam proses pembelajaran yang dilaksanakan (Sato, 2014). Pembelajaran kolaboratif lebih menekankan pada keterpaduan aktivitas bersama antar intelektual, emosi sosial siswa maupun guru dalam pembelajaran (Marhamah, dkk, 2017). Hal itu disebabkan pembelajaran kolaboratif melibatkan partisipasi aktif siswa dalam proses belajar dan meminimalisasi perbedaan antar individu. Maka penerapan model kolaboratif pada proses pembelajaran memiliki dampak terhadap hasil belajar siswa. Pembelajaran kolaboratif merupakan pembelajaran yang memberikan ruang bagi siswa dalam berkerjasama untuk meningkatkan interaksi dan hubungan belajar melalui pemberian soal sharing dan jumping (Astuti, dkk, 2019). Pembelajaran dapat dikatakan belajar kolaboratif apabila dua orang atau lebih dalam suatu kelompok bekerja bersama, memecahkan masalah bersama untuk mencapai tujuan tertentu (Anitah, dkk, 2014).

Pembelajaran berkelompok idealnya berangotakan 4 orang yang merupakan sarana paling baik untuk menstimulasi pembelajaran (Ambara, dkk, 2019). Dalam kelompok kecil 4 orang atau lebih tersebut, setiap siswa ikut berpartisipasi dalam penyelesaian masalah yang didapatkan kelompok. Adanya pemberian soal sharing dan jumping dalam proses pembelajaran memberikan manfaat kepada seluruh siswa dalam meningkatkan kemampauan kognitif, afektif, dan psikomotor baik siswa yang kognitifnya rendah maupun siswa yang memiliki kognitif yang tinggi (Fatimah, dkk, 2018). Pendapat serupa juga disampaikan oleh Ambara, dkk (2019) yang menyatakan bahwa melalui seting pembelajaran membentuk huruf $U$ pembelajaran kolaboratif mengehendaki peserta didik belajar secara bersama dan melalui pemberian soal sharing dan jumping oleh guru dengan mengharapkan siswa agar mampu mencapai tujuan pembelajaran bersama.

Perbedaan penelitian ini dengan penelitian sejenis lainnya adalah penerapan penelitian ini dilakuakan pada dua gugus yaitu Gugus II dan Gugus IX Kecamatan Buleleng. Selain itu perbedaan lainnya adalah variabel penelitian ini berfokus pada hasil belajar matematika. Tujuan penelitian ini yaitu untuk mengetahui pengaruh model pembelajaran kolaboratif terhadap hasil belajar matematika siswa kelas V di SD Gugus II dan IX Kecamatan Buleleng Tahun Pelajaran 2019/2020.

\section{Metode}

Penelitian ini dilaksanakan di pada siswa kelas V SD di Gugus II dan Gugus IX Kecamatan Buleleng, Kabupaten Buleleng. Pada dasarnya tujuan dilaksanakannya penelitian ini untuk untuk mengetahui pengaruh model pembelajaran kolaboratif terhadap peningkatan hasil belajar matematika siswa kelas V di SD Gugus II dan IX Kecamatan Buleleng. Jenis penelitian ini adalah penelitian eksperimen semu (quasi experiment), karena peneliti tidak mungkin melakukan kontrol terhadap semua variabel lain selain variabel perlakuan. Desain eksperimen semu yang digunakan dalam hal ini adalah "Posttest Only Control Group Design". Prosedur pelaksanaan desain penelitian ini terperinci pada tabel 1.

Tabel 1. Desain Post-test Only Group Design.

\begin{tabular}{lll}
\hline Kelas & Treatment & Post-test \\
\hline Eksperimen (E) & $\mathrm{X}$ & $\mathrm{O}_{1}$ \\
Kontrol (K) & - & $\mathrm{O}_{2}$ \\
\hline
\end{tabular}

Sumber: (Agung, 2014).

Populasi dalam penelitian ini adalah seluruh kelas $V$ yang berjumlah 16 kelas dengan jumlah siswa 401 yang berada di SD Gugus II dan Gugus IX Kecamatan Buleleng. Sebelum penentuan sampel, terlebih dahulu dilakukan uji kesetaraan terhadap dua belas sekolah yang menjadi populasi. Hal ini dilakukan dikarenakan perbedaan jumlah siswa kelas $V$ pada setiap sekolah dasar dan juga kemampuan siswa kelas $\mathrm{V}$ pada setiap sekolah dasar yang beranekaragam. Uji kesetaraan ini dilakukan dengan menganalisis hasil ulangan tengah semester (UTS) mata pelajaran matematika pada semester ganjil. Analisis yang digunakan dalam uji kesetaraan yaitu analisis varians satu jalur (ANAVA A). Berdasarkan hasil analisis 
varians pada taraf signifikansi $5 \%$ di SD gugus II Kecamtan Buleleng diperoleh $\mathrm{F}_{\text {hitung }}$ sebesar 2,25 sedangkan $F_{\text {tabel }}$ pada $\mathrm{db}_{\text {antar }}=4$ dan $\mathrm{db}_{\text {dalam }}=108$ sebesar 2,46 . Dengan demikian terlihat bahwa nilai $\mathrm{F}_{\text {hitung }}<\mathrm{F}_{\text {tabel }}(2,25<2,46)$, sehingga $\mathrm{H} 0$ diterima dan $\mathrm{H} 1$ ditolak. Analisis varians, pada taraf signifikansi 5\% di SD gugus IX Kecamtan Buleleng diperoleh $F_{\text {hitung }}$ sebesar 1,41 sedangkan $F_{\text {tabel }}$ pada $\mathrm{db}_{\text {antar }}=9$ dan $\mathrm{db}_{\text {dalam }}=278$ sebesar 1,91. Dengan demikian terlihat bahwa nilai $F_{\text {hitung }}<F_{\text {tabel }}(1,41<1,91)$, sehingga $\mathrm{H} 0$ diterima dan $\mathrm{H} 1$ ditolak. Dengan demikian, hasil uji kesetaraan menunjukan bahwa, tidak terdapat perbedaan yang signifikan hasil belajar Matematika siswa kelas V SD pada Gugus II dan IX Kecamatan Buleleng adalah setara.

Pemilihan sampel dalam penelitian ini dilakukan dengan cara teknik multistage random sampling dan yang dirandom adalah kelas. Multistage random sampling merupkan "Teknik pengambilan sampel secara bertahap, dari elemen populasi yang lebih besar (yang karateristiknya suadah pasti) ke elemen populasi yang lebih kecil dan begitu seterusnya" (Dantes, 2012:44). Setelah melakukan uji kesetaraan pada populasi, maka dilanjutkan dengan penentuan sampel pada suatu penelitian. Melalui teknik undian (multistage random sampling) diperoleh kelas V di SDN 1 Penarukan sebagai kelas eksperimen dan kelas $\mathrm{V}$ SDN 4 Penarukan sebagai kelas kontrol pada Gugus II Kecamatan Buleleng, dan untuk Gugus IX Kecamatan Buleleng diperoleh kelas V di SDN 1 Astina (A) sebagai kelas eksperimen dan kelas V SDN 1 Astina (B) sebagai kelas kontrol.

Metode pengumpulan data merupakan "langkah yang paling utama dalam penelitian, karena tujuan utama dari penelitian untuk mendapatkan data" (Sugiyono, 2015:308). Pada penelitian ini, data yang dikumpulan adalah data hasil belajar matematika. Pengumpulan data dilakukan dengan tujuan untuk dapat mengungkap sejauh mana pengaruh model pembelajaran kolaboratif terhadap hasil belajar matematika siswa kelas V. Uji instrumen dalam penelitian ini dilakukan untuk mendapatkan gambaran secara empirik apakah perangkat pembelajaran yang dikembangkan layak digunakan dalam penelitian. Uji instrumen ini antara lain: uji validitas isi menggunakan rumus Gregory, uji validitas butir tes menggunakan rumus korelasi point biserial, uji reliabilitas tes menggunakan rumus KR-20, uji taraf kesukaran, dan uji daya beda. Setalah dilakukan uji instrument dengan hasil dari 25 butir soal, terdapat 20 butir soal yang selanjutnya diberikan kepada siswa kelas kelompok eksperimen dan kelompok kontrol sebagai post-test. Metode yang digunakan untuk mengumpulkan data hasil belajar Matematika adalah metode tes dengan jenis pilihan ganda. Menurut Koyan (2012a:8) tes adalah "instrumen atau prosedur yang sistematis yang terdiri atas seperangkat pertanyaan atau tugas-tugas untuk mengkur suatu prilaku tertentu pada peserta didik dengan menggunakan bantuan skala numerik atau kategori tertentu". Pada penelitian ini setelah sampel diberikan perlakuan, selanjutnya sampel instrumen yang digunakan untuk memperoleh data hasil belajar matematika pada ranah kognitif adalah tes pilihan ganda yang berjumlah 20 butir soal.

Metode dan teknik analisis data yang digunakan pada penelitian ini adalah teknik analisis statistik deskriptif dan statistik inferensial. Adapun dalam penelitian ini statistik deskriptif yang digunakan yaitu mean, median, modus, dan standar deviasi. Sedangkan teknik yang digunakan untuk menganalisis data guna menguji hipotesis penelitian adalah ujit. Adapun persyaratan yang harus dipenuhi dan perlu dibuktikan untuk bisa melakukan uji hipotesis, yaitu: (1) data yang dianalisis harus berdistribusi normal, (2) kedua data yang dianalisis harus bersifat homogen. Untuk dapat membuktikan dan memenuhi persyaratan tersebut, maka dilakukanlah uji prasyarat analisis dengan melakukan uji normalitas, dan uji homogenitas. Uji Normalitas sebaran data pada penelitian ini dilakukan untuk mengetahui nilai sebaran data pada sampel benar-benar berasal dari populasi yang memiliki data beristribusi normal atau tidak dengan analisis Chi-Khuadrat. Selanjutnya nilai $x^{2}$ hitung dan juga nilai $x^{2}$ tabel dibandingkan pada (taraf signifikansi $5 \%$ ). Jika $x^{2}$ hitung $<x^{2}$ tabel, maka HO diterima, maka sampel berasal dari populasi yang berdistribusi normal (Dantes, 2017). Uji Homogenitas Varians pada penelitian ini dilakukan dengan tujuan untuk menegtahui apakah data pada penelitian ini bersifat homogen atau tidak. Setelah $F_{\text {hitung }}$ dibandingkan dengan $F_{\text {tabel }}$ pada taraf signifikansi $5 \%$ apabila hasil dari pengujian data mendapat hasil $F_{\text {hitung }}<F_{\text {tabel }}$ 
maka sampel homogen. Selanjutnya pada uji hipotesis, penelitian ini menggunakan uji-t. Adapun nilai hipotesis yang digunakan adalah $\mathrm{H} 0$ diterima ketika (t-hitung $\leq \mathrm{t}$-tabel), dan $\mathrm{H} 1$ diterima jika t-hitung lebih besar dari t-tabel (t-hitung $>$ t-tabel).

\section{Hasil dan Pembahasan}

Setelah kelompok ekperimen diberikan perlakuan menggunakan model pembelajaran Kolaboratif dan kelompok kontrol tidak diberikan perlakuan menggunakan model pembelajaran Kolaboratif, selanjutnya akan dilakukan pengukuran. Analisis data dilakukan pada masing-masing kelas yaitu kelas ekperimen dan kelas kontrol. Hasil dari analisis data statistik deskriptif disajikan pada Tabel 2.

Tabel 2. Analisis Data dengan Statistik Deskriptif

\begin{tabular}{lcc}
\hline \multirow{2}{*}{ Statistik } & \multicolumn{2}{c}{ Hasil Belajar Matematika } \\
\cline { 2 - 3 } & Kelompok Eksperimen & Kelompok Kontrol \\
\hline Mean (M) & 17,40 & 15,06 \\
Median (Md) & 18 & 15 \\
Modus (Mo) & 19 & 14 \\
Standar Deviasi (s) & 1,55 & 1,81 \\
Varians $\left(\mathrm{s}^{2}\right)$ & 2,43 & 3,31 \\
\hline
\end{tabular}

Berdasarkan analisis data dengan statistik deskriptif pada tabel 2 di atas, hasil analisis deskriptif hasil belajar Matematika menunjukan bahwa pada sebaran data kelas eksperimen bernilai negatif, karena $\mathrm{Mo}>\mathrm{Md}>\mathrm{M}(19>18>17,40)$ maka hal ini menunjukkan bahwa sebagian besar nilai kelas eksperimen cenderung tinggi. Sedangkan sebaran data pada kelas kontrol bernilai positif karena $M o<M d<M \quad(14<15<15,06)$ maka hal ini menunjukkan bahwa sebagian besar nilai kelas kontrol cenderung rendah. Ketika dikonversikan rata-rata hasil belajar matematika kelas eksperimen dan kelas kontrol dengan katagori pada skala lima, didapatkan rata-rata skor hasil belajar matematika siswa pada kelas eksperimen adalah 17,40 termasuk pada kategori tinggi. Sementara hasil rata-rata skor hasil belajar matematika siswa kelas kontrol adalah 15,06 pada ketegori tinggi.

Setelah dilakukan analisis deskriptif, maka selanjutnya dilakukan uji hipotesis. Sebelum dilakukan uji hipotesis, terlebih dahulu dilakukan uji prasyarat yang meliputi uji normalitas dan uji homogenitas. Untuk uji normalitas data menggunakan rumus Chi-kuadrat yang disajikan pada Tabel 3.

Tabel 3. Rekapitulasi Hasil Pengujian Normalitas Sebaran Data dan Homogenitas Varians

\begin{tabular}{lllllllllll}
\hline \multirow{2}{*}{ No } & \multirow{2}{*}{$\begin{array}{l}\text { Kelompok } \\
\text { Data }\end{array}$} & \begin{tabular}{l} 
Uji Notal \\
\cline { 3 - 9 }
\end{tabular} & $\mathbf{X}^{2}{ }_{\text {hitung }}$ & $\mathbf{X}^{2}$ tabel & Kesimpulan & Varians & $\mathbf{F}_{\text {hitung }}$ & $\mathbf{F}_{\text {tabel }}$ & Keterangan \\
\hline 1 & Eksperimen & 55 & 6,78 & 11,070 & Normal & 2,43 & 1,36 & 3,95 & Homogen \\
2 & Kontrol & 49 & 7,28 & 11,070 & Normal & 3,31 & 1,36 & \\
\hline
\end{tabular}

Berdasarkan hasil pengujian normalitas sebaran data pada Tabel 3 di atas, dapat diketahui bahwa 1) $\mathrm{X}^{2}$ hitung hasil post-test pada kelompok eksperimen sebesar 6,78. Sedangkan $\mathrm{X}^{2}$ hitung hasil post-test pada kelompok kontrol sebesar 7,28 , dengan $\mathrm{dk}=8-2-1$ $=5$, sehingga didapatkan $X^{2}$ tabel sebesar 11,070 pada taraf signifikan $5 \%$. Hal ini menunjukan $\left(\mathrm{X}^{2}\right.$ hitung $<\mathrm{X}^{2}$ tabel) pada taraf signifikan $5 \%$. Sehingga dapat disimpulkan bahwa sebaran data post-test pada kedua kelompok berdistribusi normal. 2) $F_{\text {hitung }}$ hasil belajar matematika kelompok eksperimen dan kelompok kontrol adalah 1,36. Sedangkan $F_{\text {tabel }}$ dengan $\mathrm{db}_{\text {pembilang }}$ $=1, \mathrm{db}_{\text {penyebut }}=102$ dengan taraf signifikansi $5 \%$ adalah 3,93. Sehingga dapat disimpuklan $F_{\text {hitung }}(1,36)<F_{\text {tabel }}(3,93)$ maka skor post-test hasil belajar matematika siswa kelompok eksperimen dan kontrol adalah homogen.

Selanjutnya akan dilakukan uji hipotesis. Kriteria pengujian hipotesis adalah $\mathrm{HO}$ ditolak jika thitung $>t_{\text {tabel, }}$, dan diperoleh dari tabel distribusi t pada taraf signifikansi 5\%, dengan derajat kebebasan $\mathrm{db}=\mathrm{n} 1+\mathrm{n} 2-2$. Hasil uji hipotesis disajikan pada Tabel 4. 
Tabel 4. Hasil Uji-t

\begin{tabular}{lllllll}
\hline Kelompok & $\mathbf{N}$ & $\mathbf{d b}$ & Mean & $\mathbf{S}^{2}$ & $\mathbf{t}_{\text {hitung }}$ & $\mathbf{t}_{\text {tabel }}$ \\
\hline Ekperimen & 55 & 102 & 17,40 & 2,43 & 7,09 & 1,983 \\
kontrol & 49 & & 15,06 & 3,31 & & \\
\hline
\end{tabular}

Berdasarkan Tabel 4, didapatkan bahwa thitung $=7,09$ dan $t_{\text {tabel }}=1,983$ dengan $\mathrm{db}=(55$ $+49)-2=102$ pada taraf signifikansi $5 \%$. Hal ini menunjukan bahwa thitung $>t_{\text {tabel }}$ sehingga $\mathrm{H}_{0}$ ditolak dan $\mathrm{H}_{1}$ diterima. Artinya Terdapat pengaruh yang signifikan terhadap hasil belajar matematika antara kelompok siswa yang dibelajarkan dengan model pembelajaran Kolaboratif dan kelompok sisiwa yang tidak dibelajarkan dengan model pembelajaran Kolaboratif pada siswa kelas V SD di Gugus II dan Gugus IX Kecamatan Buleleng Kabupaten Buleleng Tahun Pelajaran 2019/2020.

Setelah melakukan analisis penelitian, didapatkan hasil bahwa terdapat perbedaan yang signifikan terhadap hasil belajar Matematika antara kelompok siswa kelas V SD di Gugus II dan Gugus IX Kecamatan Buleleng Kabupaten Buleleng Tahun Pelajaran 2019/2020 yang dibelajarkan dengan model pembelajaran Kolaboratif, dan kelompok siswa yang tidak dibelajarakan dengan model pembelajaran Kolaboratif. Adapun hasil rata-rata post-test skor hasil belajar dari kelompok eksperimen dan kelompok kontrol $(17,4>15,06)$. Berdasarkan perhitungan uji-t diperoleh $t_{\text {hitung }}=7,09$ dan $t_{\text {tabel }}=1,983$ dimana pada taraf signifikan $5 \%$ dan $\mathrm{db}=102$. Setelah dibandingkan $t_{\text {hitung }}$ dengan $t_{\text {tabel}}$, dapat disimpulkan bahwa $t_{\text {hitung }}>\mathrm{t}_{\text {tabel}}$, sehingga $\mathrm{H} 1$ diterima dan $\mathrm{H} 0$ ditolak. Hasil penelitian ini menunjukan kemampuan pemecahan masalah matematika kelompok eksperimen berbeda dengan kelompok kontrol. Adapun yang mendasari dari perbedaan hasil belajar pada kelompok eksperimen dengan kelompok kontrol tersebut adalah sebagai berikut.

Pertama, model pembelajaran Kolaboratif merupakan model pembelajaran yang memotivasi siswa untuk berkolaborasi dan lebih aktif dalam memecahkan masalah baik secara individu maupun dalam berkelompok. Hal tersebut didukung oleh penelitain yang dilakukan (Anggreni, dkk, 2019) menyatakan bahwa pembelajaran kolaboratif mampu menciptakan pembelajaran yang efektif dengan sistem kelompok, sehingga siswa memiliki motivasi untuk belajar karena pembelajarannya yang interaktif baik antara siswa dengan siswa dalam satu kelompok, siswa dengan siswa yang berbeda kelompok, dan siswa dengan guru. Selain itu pada pembelajaran kolaboratif siswa dilatih untuk berkomunikasi dengan baik, memberikan pendapat atau informasi, mempertanggungjawabkan apa yang telah dikerjakan. Pendapat serupa juga disampaikan oleh (Ode, dkk, 2017) menyatakan bahwa pembelajaran kolaboratif mampu meningkatkan kemampuan bekerja sama dan kemampuan berkomunikasi siswa di kelmpok. Dalam model pembelajaran tersebut, guru menjadi fasilitator yang mengarahkan siswa dalam proses pembelajaran, sehingga siswa menjadi lebih aktif dan mampu memecahkan suatu masalah yang mereka dapatkan baik secara individu maupun berkelompok. Pada dasarnya pembelajaran penerapan model pembelajaran kolaboratif membuat siswa menjadi termotivasi untuk belajar di kelas. Hal ini dikarenakan model pembelajaran kolaboratif memberikan keleluasaan siswa dalam menyampaikan pendapatnya di dalam kelompok. Pembelajaran yang bisa memebuat siswa menjadi leluasa dalam menyampaikan pendapatnya di dalam kelompok mamapu meningkatkan kemampuan berkomunikasi siswa. Menurut Simbolon (2017) pembelajaran berkelompok mampu meningkatkan motivasi belajar perserta didik, sehingga mau bekerja sama dengan teman kelompoknya untuk mengatasi permasalahan yang dihadapi.

Kedua, model pembelajaran kolaboratif dapat meminimalisir masalah belajar yang sering dialami oleh siswa. Hal ini dikarenakan dalam penerapan model pembelajaran ini, sikap berpikir kritis siswa dalam memecahkan masalah pada saat berkelompok akan ditingkatkan. Setelah siswa mendapatkan soal atau masalah oleh guru berupa soal sharing dan jumping, siswa akan bekerjasama untuk memecahkan soal atau masalah didalam kelompok. Pada saat siswa menyelesaikan masalah, siswa dibelajarkan bagaimana cara 
bermusyawarah untuk menyelesaikan tugas atau masalah. Santosa (2018) berpendapat bahwa pembelajaran yang memuat adanya aktivitas kerja sama antarsiswa dapat meningkatkan keaktifan siswa, menumbuhkan kemauan diri untuk belajar, dan mealatih kecakapan bekerja dalam kelompok. Setelah siswa mampu menyelesaikan masalah yang diberikan oleh guru secara berkelompok, masing-masing kelompok juga diarahkan untuk menyampaikan hasil diskusinya di depan kelas yang akan diperhatikan oleh semua siswa. Setelah salah satu kelompok menyampaikan hasil diskusinya di depan kelas, siswa atau kelompok yang lain diberikan kesempatan untuk menanggapi atau menambahkan jawaban dari hasil diskusi kelompok mereka. Sehingga proses pembelajaran didalam kelas tidak lagi berpusat pada guru dan proses pembelajaran tidak membosankan atau monoton. Lumentut, dkk (2015) berpendapat bahwa diterapkannya pembelajaran yang menekankan pada kolaborasi siswa, mampu meningkatkan keaktifan siswa dalam diskusi dan tanya jawab. Guru hanya berperan sebagai motivator dan fasilitator dalam proses pembelajaran. Siswa sangat antusias dalam pembelajaran, dan mampu bekerjasama dengan siswa lain dalam penerapan pembelajaran dengan model ini. Kelompok sisiwa yang dibelajarkan dengan menggunakan model pembelajaran kolaboratif, menunjukan hasil yang lebih baik. Sebagian besar siswa sudah aktif dalam berkolaborasi pada saat proses pembelajaran yang berdampak pada peningkatan hasil belajar siswa melalui pemeberian soal sharing dan jumping. Hal tersebut sejalan dengan penelitian dari (Marhamah, dkk, 2017) yang menyatakan hal penting dari pembelajaran kolaboratif ialah bagaimana membuat siswa mejadi fokus dalam belajar yang berdampak hasil belajar siswa yang meningkat, dapat diwujudkan dengan dengan pemberian sharing task dan jumping task secara bertahap.

Sedangkan pada kelompok yang tidak dibelajarkan dengan model pembelajaran kolaboratif masih cendrung kurang optimal. Kurang termotivasi Proses pembelajaran yang masih cendrung berpusat pada guru, dimana guru masih menyampaikan materi lebih banyak dengan metode berceramah, latihan soal yang kurang, serta penggunaan model yang kurang inovatif. Hal ini mengakibatkan siswa yang kurang aktif dalam proses pembelajaran yang berdampak pada hasil belajar siswa. Hasil penelitian ini juga sejalan penelitian yang dilakukan oleh Utami (2019) juga membuktikan bahwa pembelajaran dengan menggunakan model pembelajaran kolaboratif dapat memudahkan siswa dalam belajar hal ini dikarenakan pembelajaran yang menerapkan model pembelajaran kolaboratif menjadi lebih bermakna, mendorong siswa untuk bertanggung jawab terhadap pembelajaran, yang dapat meningkatkan hasil belajar kognitif sesuai dengan yang diharapkan. Penelitian yang dilakukan oleh (Mahendra, dkk, 2018) juga mendukung hasil penelitian ini yang menyatakan bahwa model pembelajaran kolaboratif mampu meningkatkan hasil belajar siswa, yang disebabkan oleh pembelajaran kolaboratif sangat efektif karena memungkinkan peserta didik dapat belajar secara optimal, yang pada gilirannya dapat meningkatkan prestasi belajar peserta didik secara signifikan.

Proses pembelajaran model pembelajaran Kolaboratif pada kelompok eksperimen dan pembelajaran konvensional pada kelompok kontrol di Gugus II dan Gugus IX Kecamatan Buleleng, pada penelitian ini menunjukkan bahwa terdapat perbedaan pada hasil matematika siswa. Hal ini dapat dilihat dari data hasil belajar matematika siswa. Secara deskriptif, hasil belajar matematika siswa pada kelompok eksperimen lebih tinggi dibandingkan dengan kelompok kontrol.

\section{Simpulan}

Berdasarkan hasil penelitian dan juga pembahasan, dapat disimpulkan bahwa hasil belajar matematika siswa yang dibelajarkan model pembelajaran Kolaboratif memiliki pengaruh yang signifikan. Hal ini ditunjukkan oleh nilai rerata hitung, kelompok siswa yang dibelajarkan dengan menggunakan model pembelajaran Kolaboratif memiliki nilai rata-rata lebih tinggi dari pada kelompok siswa yang tidak dibelajarkan menggunakan model pembelajaran Kolaboratif $(17,4>15,06)$. Selain itu, diperoleh hasil analisis uji-t yang diketahui bahwa $t_{\text {hitung }}=7,09>\mathrm{t}_{\text {tabel }}=1,983$ yang berarti $\mathrm{H} 0$ ditolak dan $\mathrm{H} 1$ diterima. Dengan demikian, dapat disimpulkan bahwa terdapat pengaruh yang signifikan implementasi model 
pembelajaran Kolaboratif berpengaruh terhadap hasil belajar Matematika pada siswa kelas $\mathrm{V}$ SD di Gugus II dan Gugus IX Kecamatan Buleleng Tahun Pelajaran 2019/2020.

\section{Daftar Pustaka}

Agung, A. A. G. (2014). Metodologi Penelitian Pendidikan. Singaraja: Aditya Media Publishing.

Ambara, I. M. Y., Margunayasa, I. G., \& Kusmariyatni, N. N. (2019). Pengembangan perangkat pembelajaran kolaboratif pada mata pelajaran matematika topik pengolahan data siswa kelas V SD. Premiere Educandum: Jurnal Pendidikan Dasar Dan Pembelajaran, 9(2), 112. https://doi.org/10.25273/pe.v9i2.4671

Anggarawati, I. G. . A., Kristiani, R. M., \& Asri, I. G. . S. A. (2014). Pengaruh Make A Match Berbantuan Media Kartu Gambar Terhadap Hasil Belajar IPS SD. Undiksha, 2(1). Retrieved from http://ejournal.undiksha.ac.id/index.php/JJPGSD/article/view/2146

Anggreni, I. D. A. Y. D., Margunayasa, I. G., \& Kusmariyatni, N. N. (2019). Pengaruh Model Pembelajaran Kolaboratif Ditinjau Dari Motivasi Berprestasi Terhadap Hasil Belajar IPA I. Indonesian Journal Of Educational Research and Review, 2(2), 65. https://doi.org/10.23969/jp.v1i1.224

Anitah, W. ., \& Dkk. (2014). Strategi Pembelajaran di SD. Tanggerang Selatan: Universitas Terbuka.

Ardila, A., \& Hartanto, S. (2017). Faktor Yang Mempengaruhi Rendahnya Hasil Belajar Matematika Siswa Mts Iskandar Muda Batam. PYTHAGORAS: Jurnal Program Studi Pendidikan Matematika, 6(2), 175-186. https://doi.org/10.33373/pythagoras.v6i2.966

Astuti, P. H. M., Margunayasa, I. G., \& Suarjana, I. M. (2019). Pengembangan Perangkat Pembelajaran Kolaboratif pada Mata Pelajaran Matematika Topik Kubus dan Balok. 3(3), 271-280.

Dantes, N. (2012). Metodelogi Penelitian. Yogyakarta: CV. Andi Offset.

Dantes, N. (2017). Desain Eksperimen dan Analisis Data. Depok: Rajawali Pers.

Fatimah, I., Hendayana, S., \& Supriatna, A. (2018). Didactical design based on sharing and jumping tasks for senior high school chemistry learning. Journal of Physics: Conference Series, 1013(1). https://doi.org/10.1088/1742-6596/1013/1/012094

Hariadi, M. F. (2019). Identifikasi Kesulitan Belajar Siswa Kelas V Pada Polak Ntb. Jurnal Pendidikan Dasar, 10(1), 121-131.

Hayati, R., Fauzan, A., Iswari, M., \& Khaidir, A. (2018). Designing of Holistic Mathematic Education Model Based-"System Among" at Low Grade Elementary School. IOP Conference Series: Materials Science and Engineering, 335(1). https://doi.org/10.1088/1757-899X/335/1/012130

Japa, I. G. N., \& Suarjana, I. M. (2014). Pendidikan Matematika III. Singaraja: Universitas Pendidikan Ganesha.

Japa, I. G. N., \& Suarjana, I. M. (2015). Pendidikan Matematika I. Singaraja: Universitas Pendidikan Ganesha.

Koyan, I. W. (2012). Statistik Pendidikan Teknik Analisis Data Kuantitatif. Singaraja: Universitas Pendidikan Ganesha Press.

Lumentut, C. P., Ali, M. T. M., \& Hasbi, M. (2015). Peningkatanhasil Belajar Siswa Kelas VIII SMPN 14 Palu Denganmodel Pembelajaran Kooperatif Tipe Nht Berbantuan Blok Aljabar Padamateri Perkalian Faktor Bentuk Aljabar. Jurnal Elektronik Pendidikan Matematika Tadulako, 2(3), 239-248.

Mahendra, I. W. E., Jayantika, I. G. A. N. ., \& Mintarti, N. G. P. . (2018). Pengaruh Model Pembelajaran Kolaboratif Terhadap Hasil Belajar Matematika Dengan Mengontrol Bakat Numerik Peserta DidiK. Joornal of Songke Math, 1(2), 10-21.

Marhamah, Mustafa, \& Melvina. (2017). Pengaruh Model Pembelajaran Kolaboratif Berbasis Lesson Study Learning Community (LSLC). Jurnal IImiah Mahasiswa (JIM) Pendidikan Fisika, 2, 277-282.

Monawati, \& Yamin, M. (2016). Upaya Meningkatkan Hasil Belajar Siswa Melalui Lesson Study Pada Penjumlahan Pecahan Di Kelas Iv Sdn Lamsayeun. Jurnal Pesona Dasar, 
3(4), 12-21.

Ode, N. M. Y., Bialangi, N., \& Ischak, N. I. (2017). Pengaruh Pembelajaran Kolaboratif Terhadap Hasil Belajar Siswa Pada Materi Tata Nama Senyawa Kimia di SMA Negeri 1 Telaga Biru T . A 2015 / 2016. 12(2), 157-164.

Permana, R. H. (2019). Survei Kualitas Pendidikan PISA 2018: RI Sepuluh Besar dari Bawah. Retrieved November 23, 2019, from Detik News (online) website: https://news.detik.com/berita/d-4808456/survei-kualitas-pendidikan-pisa-2018-risepuluh-besar-dari-bawah

Pratiwi, N. K. (2015). Pengaruh Tingkat Pendidikan, Perhatian Orang Tua, dan Minat Belajar Siswa Terhadap Prestasi Belajar Bahasa Indonesia Siswa SMK Kesehatan di Kota Tangerang Noor. Jurnal Pujangga, Vol. 1(No 2), 75-105.

Santosa, D. S. S. (2018). Manfaat Pembelajaran Kooperatif Team Games Tournament (TGT) Dalam Pembelajaran. Jurnal Humaniora, 1(1), 1-5.

Sato, M. (2014). Mereformasi Sekolah Konsep dan Praktek Komunitas Belajar. Tokyo: Iwanami Shoten Publishers.

Setyaningsih, N. H. (2014). Model Kolaboratif Tipe Investigasi Kelompok Sebagai Upaya Peningkatan Kemampuan Apresiasi Prosa Mahasiswa. Lingua, 10(1).

Simbolon, M. (2017). Penerapan Model Pembelajaran Kooperatif Dalam Meningkatkan Motivasi Serta Kreativitas Dan Hasil Belajar Siswa Di SMP Negeri 5 Tebing Tinggi. School Education Journal, 7(2), 230-241. Retrieved from https://jurnal.unimed.ac.id/2012/index.php/school/article/view/6860

Sribawana, S. I. P. S., Kusmariyatni, N. N., \& Suwatra, I. W. (2017). Pengaruh Model Pembelajaran Problem Based Learning Berbantuan Media Gambar Terhadap Hasil Belajar IPA Kelas IV Metode pembelajaran yang digunakan oleh guru selama proses pembelajaran IPA berlangsung adalah ceramah dan. 5(2), 1-12.

Sugiyono. (2015). Metode Penelitian Kuantitatif Kualitatif dan R\&D. Bandung: Alfabeta.

Susanto, A. (2013). Teori Belajar \& Pembelajaran di Sekolah Dasar. Jakarta: Kencana Prenada Media Group.

Utami, N. M. Y., Margunayasa, I. G., \& Kusmariyatni, N. N. (2019). Pengaruh model pembelajaran kolaboratif tipe. 2(2), 139-151.

Warti, E. (2018). Pengaruh Motivasi Belajar Siswa terhadap Hasil Belajar Matematika Siswa di SD Angkasa 10 Halim Perdana Kusuma Jakarta Timur. Mosharafa: Jurnal Pendidikan Matematika, 5(2), 177-185. https://doi.org/10.31980/mosharafa.v5i2.273 